\title{
Potential of Open Data in the Agricultural eGovernment
}

\author{
V. Vostrovský, J. Tyrychtr, M. Ulman \\ Faculty of Economics and Management, Czech University of Life Sciences Prague, Czech Republic
}

\begin{abstract}
Anotace
Článek prezentuje přehled současného výzkumu potenciálu otevřených dat a jejich využití v zemědělství. Otevřená data jsou prezentována prostřednictvím konceptů informační potřeby a transformačních míst v zemědělských podnicích. Jako př́klady možných př́ležitostí a stimulů pro otevřená data jsou uvedeny reálné př́iklady využití otevřených formátů (Open Office XML, CSV, ODS a RDF) a analýz dat s přidanou hodnotou na Portálu farmáře, který je vedoucím informačním zdrojem v českém zemědělství. Na základě rešerše literatury a analýzy sekundárních dat je v článku uvedena série dalších výzkumných otázek.
\end{abstract}

\section{Klíčová slova}

Open data, informační potřeba, informační systémy, ekonomie Open Dat, Open eGovernment, Zemědělský eGovernment.

\begin{abstract}
The paper presents overview of current research on open data potential and use in the agriculture. Open data are described through the concepts of information need and transformation places in the agricultural enterprise. Opportunities and stimuli of open data for agriculture are discussed such as real use cases of open formats (Open Office XML, CSV, ODS and RDF) and suggestions of value-added analysis of data available at eAGRI Portal that is leading information source in Czech agriculture. Based on the literature review and secondary data analysis a series of further research questions is provided in the conclusion.
\end{abstract}

\section{Key words}

Open data, information need, information systems, Open data economy, Open eGovernment, Agricultural eGovernment.

\section{Introduction}

The issue of the open data has recently been subject of intense research and discussions. This topic is relevant especially in relationship with the public sector in which following principles are implemented:

- publishing: What is not secret can be published',

- openness: make available as much information about your own activities, decisions, rules, and financial flows as possible,

- availability: publish the information in available and understandable form,

- client-side control: transfer the relevance control of open data from publisher to recipient,

- free access: keep the open data available free of charge,
- open standards: comply with the open standards and data quality standards (Kučera and Chlapek, 2014; Open Government Standards, 2012).

In developing open data policies, governments aim to stimulate and guide the publication of government data and to gain advantages from its use. Currently there is a multiplicity of open data policies at various levels of government, whereas very little systematic and structured research has been done on the issues that are covered by open data policies, their intent and actual impact (Zuiderwijk, Janssen, 2014). By paper Luna-Reyes et al. (2014) this open data movement, although very recent, has begun to promote research to explore benefits and barriers (Janssen et al., 2012, Zuiderwijk et al., 2012), requirements and technical facilities to pro-mote value creation (Zuiderwijk et al., 2012, Arzberger et al., 2004), and policy issue and im-plications (Bertot, Choi, 2013). 


\begin{tabular}{|c|c|c|c|}
\hline & $\begin{array}{l}\text { Drive Revenue through } \\
\text { multiple areas }\end{array}$ & $\begin{array}{l}\text { Cut Costs and Drive } \\
\text { Efficiency }\end{array}$ & $\begin{array}{l}\text { Generate Employment } \\
\text { and develop future-proof skills }\end{array}$ \\
\hline $\begin{array}{l}\text { Benefit } \\
\text { to Government }\end{array}$ & $\begin{array}{l}\text { - Increased tax revenues } \\
\text { though in-creased economic } \\
\text { activity } \\
\text { - Revenues through } \\
\text { selling high value added } \\
\text { information for a price }\end{array}$ & $\begin{array}{l}\text { - Reduction in transactional } \\
\text { costs } \\
\text { - Increased service efficiency } \\
\text { through linked data }\end{array}$ & $\begin{array}{l}\text { - Create jobs in current } \\
\text { challenging times } \\
\text { - Encourage entre-preneurship }\end{array}$ \\
\hline $\begin{array}{l}\text { Benefit } \\
\text { to Private Sector }\end{array}$ & $\begin{array}{l}\text { Drive new business } \\
\text { opportunities }\end{array}$ & $\begin{array}{l}\text { Reduced cost by not having } \\
\text { to invest in conversion of } \\
\text { raw government data } \\
\text { - Better decision making } \\
\text { based on accurate } \\
\text { information }\end{array}$ & - Gain skilled workforce \\
\hline
\end{tabular}

Source: (Tinholt, 2013)

Table 1: Economic benefits of open data to government and private sector.

Increasingly open data systems allowing individuals to trace and use information at all levels in companies require open and flexible employees, and transparency (Kjellberg, Werneman, 2000). An illustrative example of open data related business success has been the making of data from the military GPS satellite navigation project available for public use. The value of the business activities related to this technology has reached millions of dollars since. The open data currently finds its main use in traffic, logistics, health care, and insurance services (Chui et al., 2014).

The agriculture sector is a unique sector due to its strategic importance for both citizens (consumers) and economy (regional and global) that ideally should make the whole sector a network of interacting organizations. Rural areas are of particular importance with respect to the agrifood sector and should be specifically addressed within this scope (Charvat et al., 2014). Agriculture Secretary Tom Vilsack, along with Bill Gates, and U.S. Chief Technology Officer Todd Park, April 29, 2013 kicked off a two-day international open data conference, saying that data "is among the most important commodities in agriculture" and sharing it openly increases its value (G-8, 2013).

The goal of this article is to define the meaning and the benefits of open data in the agricultural sector, including the identification of possibilities and assumptions for their meaningful use, given the existing information needs and appropriate disposition.

\section{Materials and methods}

The required information set at the same time depends not only on the place of its use (the decision making point), but also on the experiences and knowledge of the management entity (Říhová, 1996). The nature of information, which is a subject of this need, possibly summariz-es the best the system approach definition specified as: "Information is the process of becom-ing informed; it is dependent on knowledge, which is processed data" (Zins, 2007). Based on this definition, a relationship of information to data, as well as knowledge can be defined as:

\section{DATA $\rightarrow$ INFORMATION $\rightarrow$ KNOWLEDGE}

The level of the information need in the agricultural sector is relatively high, which is a logical consequence of the existing diversification of the pursued activities in a typical agricultural enterprise. This diversification is inherent to the very nature of agriculture, and the corresponding endeavour to target various production domains in order to mitigate the potential risks. This is among other solutions accomplished by parallel growing of several crop species in one year. In case the yields from one species are unsatisfactory, the yields from the others can partially cover for the loss making it less damaging for the agricultural enterprise. To the in-creasing information need in the agricultural sector thus also contributes that:

- many agricultural activities are affected by the significant lack of available experts or other information sources;

- many problems corresponding to these activities require timely and highly qualified solution; 
- the nature of agricultural production requires cooperation of many subjects, such as farmers, phytosanitary specialist, fertilizer producers, scientists and managers that could use open data from their specialties, however open data are lacking or unknown or available in closed proprietary formats (Dengel, 2013).

The diversification of the activities pursued is the core determinant for the corresponding information resources and information systems of agricultural enterprises. The type scale of software components of such information systems describes the following Graph 1 (Vostrovský et al., 2013).

With the existing information need closely corresponds to so-called transformation place (TP). The information need is then defined as a specific set of information required for proper functioning of a TP. The diversification of agricultural activities, as described higher, is logically reflected in the amount of TP in the typical agricultural enterprise. The set of information needs of individual TP in fact determines the required information systems and information resources. Below is shown depicts how the set of TPs in a typical agricultural enterprise can be derived..

It is obvious that every TP does not necessarily need to be personally maintained by one specific manager. In smaller agricultural businesses, a single manager often operates several TPs at the same time because of the personal dispositions of such entities.

The information need of TP in agriculture relates to following types of information:

- technological information - in the agricultural enterprise relates mainly to matters of what to do, and how to do it,

- value-assessing information - express the financial burden of realised activities,

- dynamic information - relates to the time properties of these activities (when and up to when realize them).

Every individual TP thus shows specific information need, while the union of these sectional information needs represents the total information need of the individual enterprise, which should be covered by its information resources. If not, it is necessary to get the missing infor-mation from the external sources. This can determine the space of open data use in the agricul-tural sector.

When we analyse the type of the constitution of required information coverage of agricultural enterprises (see Graph 1), the relatively low share of software used for data analysis can be observed, which can be caused by the difficulty and complexity of such software solutions. On the other hand, the demand for data (information) evaluated by such a kind of software is high, as obvious from the Graph 2.

Chosen way of publication of open data must satisfy the following conditions:

- transparency, i.e. putting data sets in a catalogue in searchable format (.xls, .mdb),

- legal openness, i.e. publication of data under an open license,

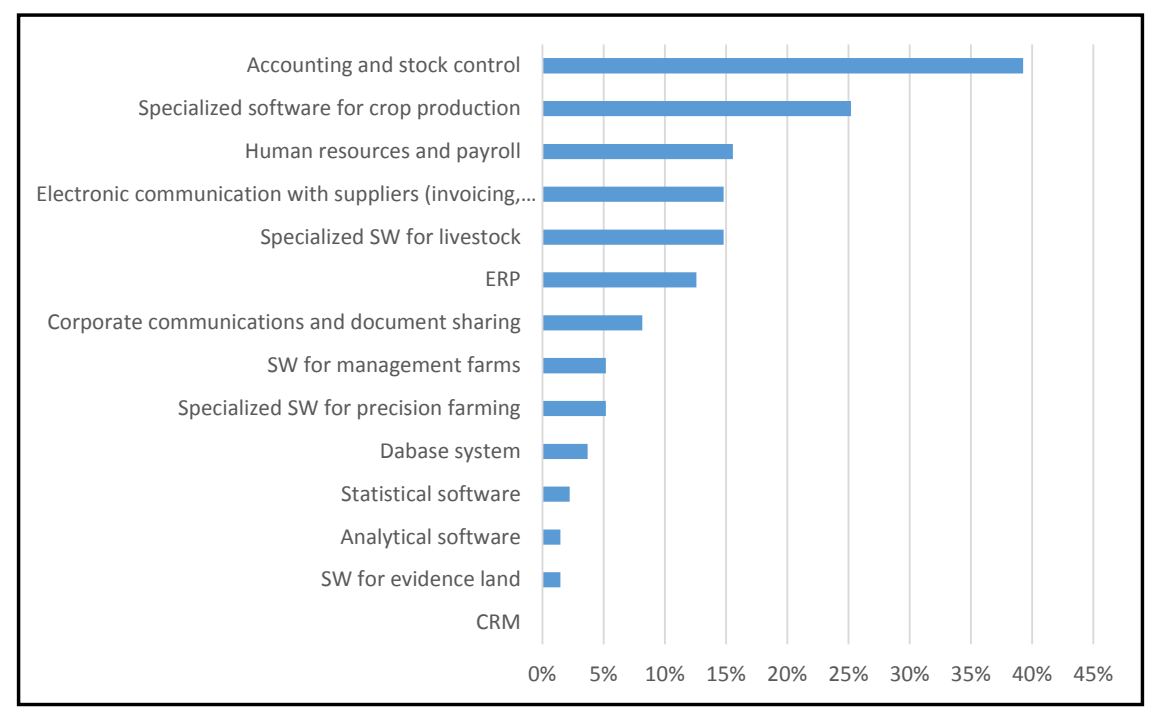

Source: (Vostrovský et al., 2013)

Graph 1: Types of software used for satisfying information needs in Czech small farms. 


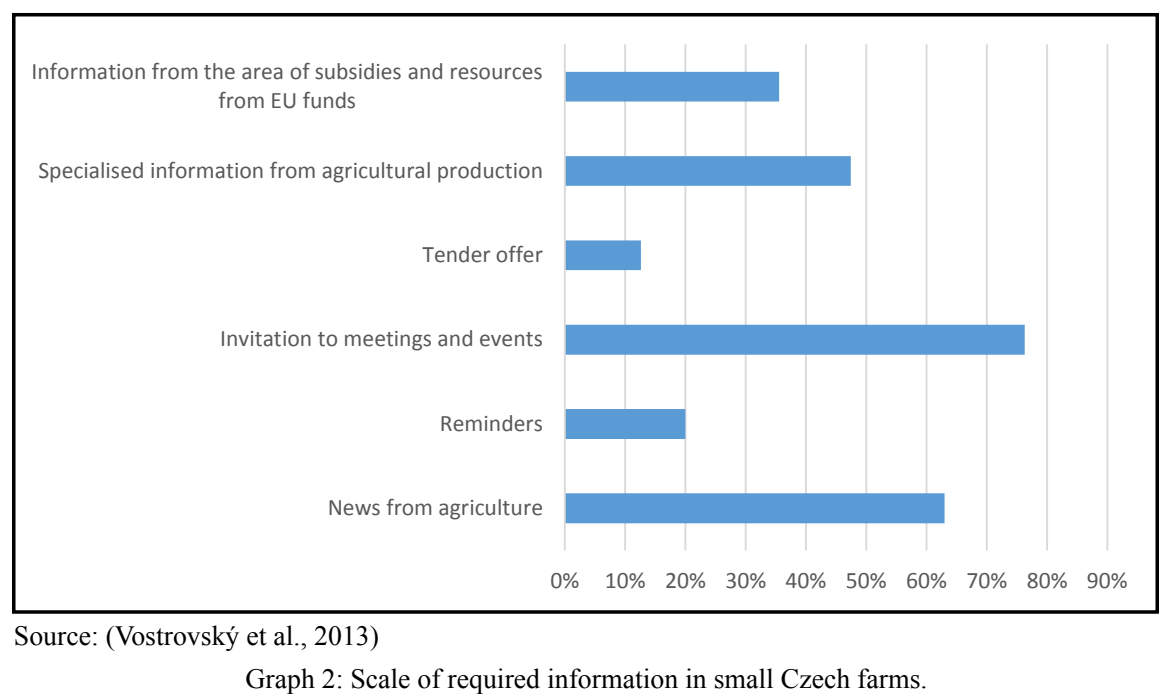

- technical openness, i.e. publication of data in a standard machine-readable format

- comprehensibility expression,

- availability and originality, ie. to publish individual data sets as a whole and unaltered,

- possibility of the aggregation of partial data.

To increase the potential of open data it will be appropriate to publish this data in a transparent form. The presentation in the form of interactive maps can be very suitable in this context.

\section{Results and discussion}

Open data as an economic stimulus in the agricultural sector

If open data should fulfill its purpose in the agriculture it must be published in an acceptable form. For this purpose, there are variety of suitable formats available:

\section{- Office Open XML:}

MS Office 2007-2013 suit documents that use the new Office Open XML (OOXML) format, are the most widely used electronic documents by a large number of users in the world $(\mathrm{Fu}$ et al., 2014) (Figure 1).

\section{- Format CSV (Comma-Separated Values):}

Format CSV is comma separated variable files. CSV files can also be read and pro-cessed by Microsoft $®$ Excel (Cremin, 2001) (Figure 2).

\section{- Format ODS (Open Document Spreadsheet):}

OpenDocument format (ODF) is an XML-based open standard file format for office documents such as these. ODF is application-, platformand vendor-neutral, and thereby facilitates broad interoperability of office documents (Weir, 2009) (Figure 3).

\section{- Format RDF (Resource Description Framework):}

The Resource Description Framework (RDF) is a framework for representing infor-mation in the Web (Klyne, Carroll, 2006) (Figure 4).

The chosen format of open data significantly predetermines so-called degree of openness. In this context it should be noted that the chosen format must be available to the provider and recipient of open data. Tim Berners-Lee, the inventor of the Web and Linked Data initiator, suggested a 5 star deployment scheme for Open Data (Berners-Lee, 2012) (Figure 5).

Own potential of open data in potential of open data in the agricultural sector (PODAS) can be defined as

$$
\text { PODAS }=\mathrm{f}(C, D P, R D, W B, S A, H W)
$$

where $C$ is content (ie. presented data set), $D P$ is provider of open data, (ie. his experience, skills, qualification, computer literacy),

$R D$ is recipient of open data (ie. his experience, skills, qualification, computer literacy),

$W B$ is web browser (ie. the its type, quality, version),

$S A$ is software amenities of the provider and recipient open data (i.e. the its type, quality, version, development tools for web development, and Tools for Promoting accessibility, (XHTML validators, CSS validators), 


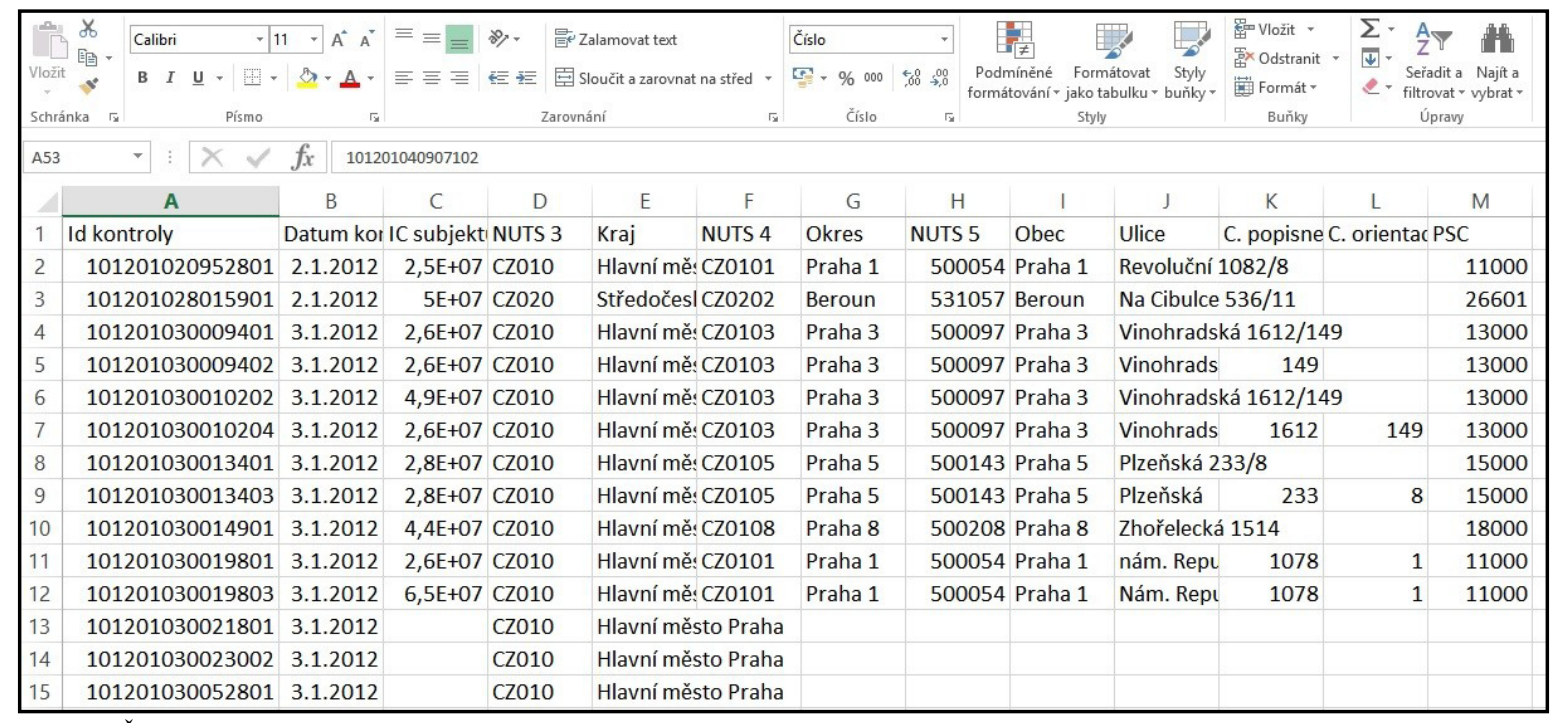

Source: (ČOI, 2013)

Figure 1: Example of open data publishing in the format .xlsx.

Soubor Úpravy Formát Zobrazeni Nápově̀d

II kontroly;Datum kontroly;IC subjektu;NUTS 3;Kraj;NUTS 4;Okres;NUTS 5;Obec;Ulice;C. popisne;C. orientacni;PSC 101201020952801;2.1.2012;24693782;CZ010;Hlavní město Praha;CZ0101;Praha 1;500054;Praha 1;Revoluční 1082/8;;;11000 101201028015901;2.1.2012;49824961;CZ020;Středočeský kraj;CZ0202;Beroun;531057;Beroun;Na Cibulce 536/11;;;26601 101201030009401;3.1.2012;26470519;CZ010;Hlavní město Praha;CZ0103;Praha 3;500097;Praha 3;Vinohradská 1612/149;;;1: 101201030009402;3.1.2012;26001900;CZ010;Hlavní město Praha;CZ0103;Praha 3;500097;Praha 3;Vinohradská;149;;13000 101201030010202;3.1.2012;49355911;CZ010;Hlavní město Praha;CZ0103;Praha 3;500097;Praha 3;Vinohradská 1612/149;;;1: 101201030010204;3.1.2012;26491788;CZ010;Hlavní město Praha;CZ0103;Praha 3;500097;Praha 3;Vinohradská;1612;149;1306 101201030013401;3.1.2012;27539385;CZ010;Hlavní město Praha;CZ0105;Praha 5;500143;Praha 5;Plzeñská 233/8;;;15000 101201030013403;3.1.2012;27879330;CZ010;Hlavní město Praha;CZ0105;Praha 5;500143;Praha 5;Plzeňská;233;8;15000 101201030014901;3.1.2012;44012373;CZ010;Hlavní město Praha;CZ0108;Praha 8;500208;Praha 8;Zhořelecká 1514;;;18000 101201030019801;3.1.2012;26447142;CZ010;Hlavní město Praha;CZ0101;Praha 1;500054;Praha 1;nám. Republiky;1078;1;116 101201030019803;3.1.2012;64949974;CZ010;Hlavní město Praha;CZ0101;Praha 1;500054;Praha 1;Nám. Republiky;1078;1;116 101201030021801;3.1.2012;;CZ010;Hlavní město Praha;;;;;;; ;

101201030023002;3.1.2012;;CZ010;Hlavní město Praha;;;;;;;;

101201030052801;3.1.2012;;CZ010;Hlavní město Praha;;;;;;;

101201030052803;3.1.2012;;CZ010;Hlavní město Praha;;;;;;;;

101201030152802;3.1.2012;27950581;CZ010;Hlavní město Praha;CZ0104;Praha 4;500119;Praha 4;Hornokrčská;39;;14000

101201030905701;3.1.2012;27185991;CZ020;Středočeský kraj;CZ0208;Nymburk;537004;Nymburk;Dopravní (K Letišti);2212;

101201030905702;3.1.2012;26415623;CZ020;Středočeský kraj;CZ020A;Praha-západ;539571;Průhonice;Uhříněveská ul.;;;25: 101201030907601;3.1.2012;;CZ010;Hlavní město Praha;;;;;;; ;

101201030910901;3.1.2012;25067583;CZ010;Hlavní město Praha;CZ0101;Praha 1;500054;Praha 1;náměstí Republiky;1;;1106 101201030910904;3.1.2012;26848601;CZ010;Hlavní město Praha;CZ0101;Praha 1;500054;Praha 1;nám. Republiky 1078/1;;;: 101201030911201;3.1.2012;;CZ010;Hlavní město Praha;;;;;;;

101201030911202;3.1.2012;62966677;CZ010;Hlavní město Praha;CZ0106;Praha 6;500178;Praha 6;Suchdolské nám. 445;;;16! 101201030912101;3.1.2012;;CZ010;Hlavní město Praha;;;;;;;;

101201030912401;3.1.2012;;CZ010;Hlavní město Praha;;;;;;;;

101201030912402;3.1.2012;28924177;CZ010;Hlavní město Praha;CZ0104;Praha 4;500119;Praha 4;K hájovně;671;14;14200

101201030912701;3.1.2012;44012373;CZ010;Hlavní město Praha;CZ0108;Praha 8;500208;Praha 8;Mazurská 484/2;;;18100 101201030950502;3.1.2012;25104080;CZ010;Hlavní město Praha;CZ0105;Praha 5;500143;Praha 5;Plzeňská 233/8;;;15000

Source: (ČOI, 2013)

Figure 2: Example publishing open data in the format .csv. 


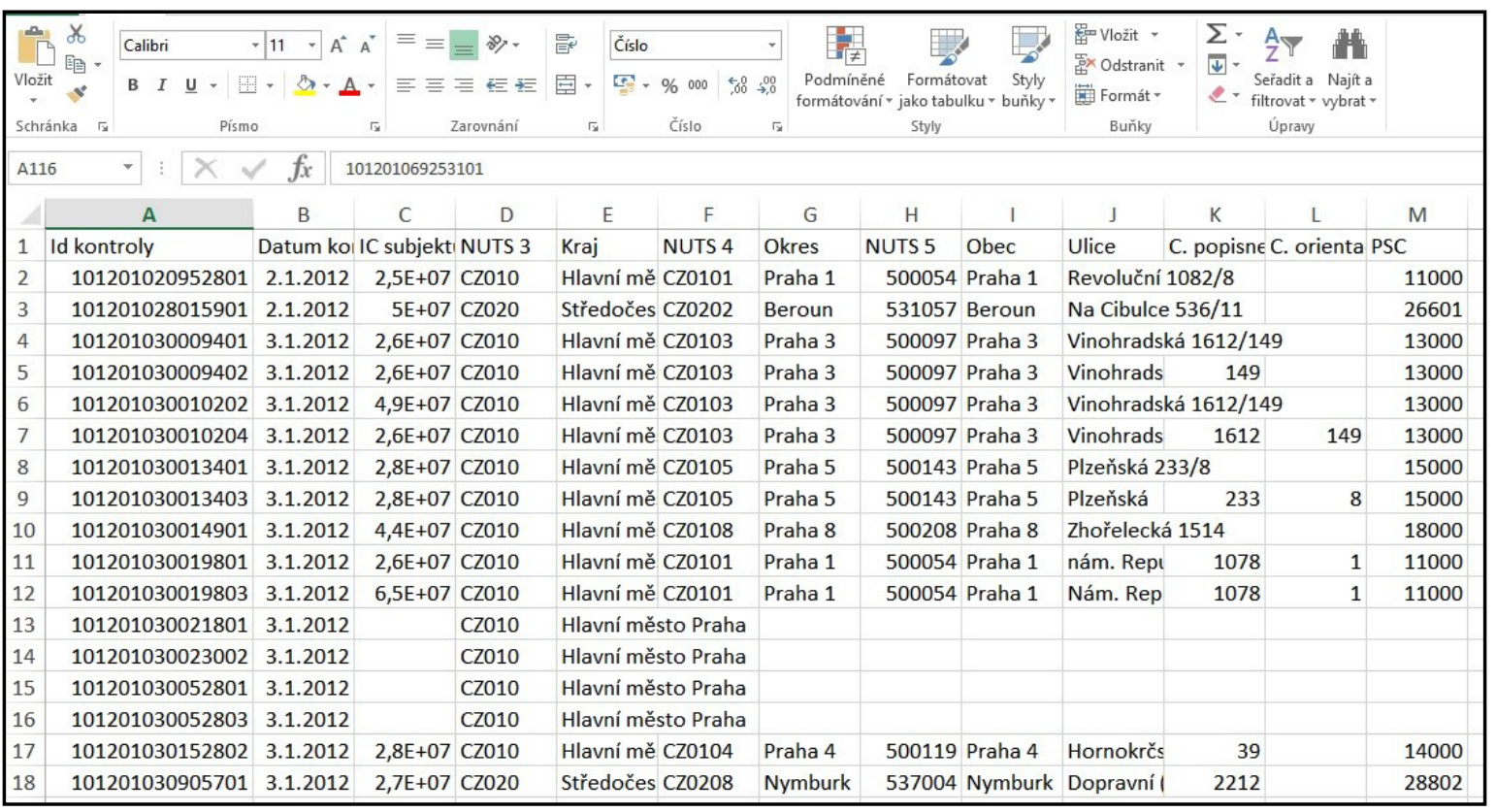

Source: (ČOI, 2013)

Figure 3: Example publishing open data in the format .ods.

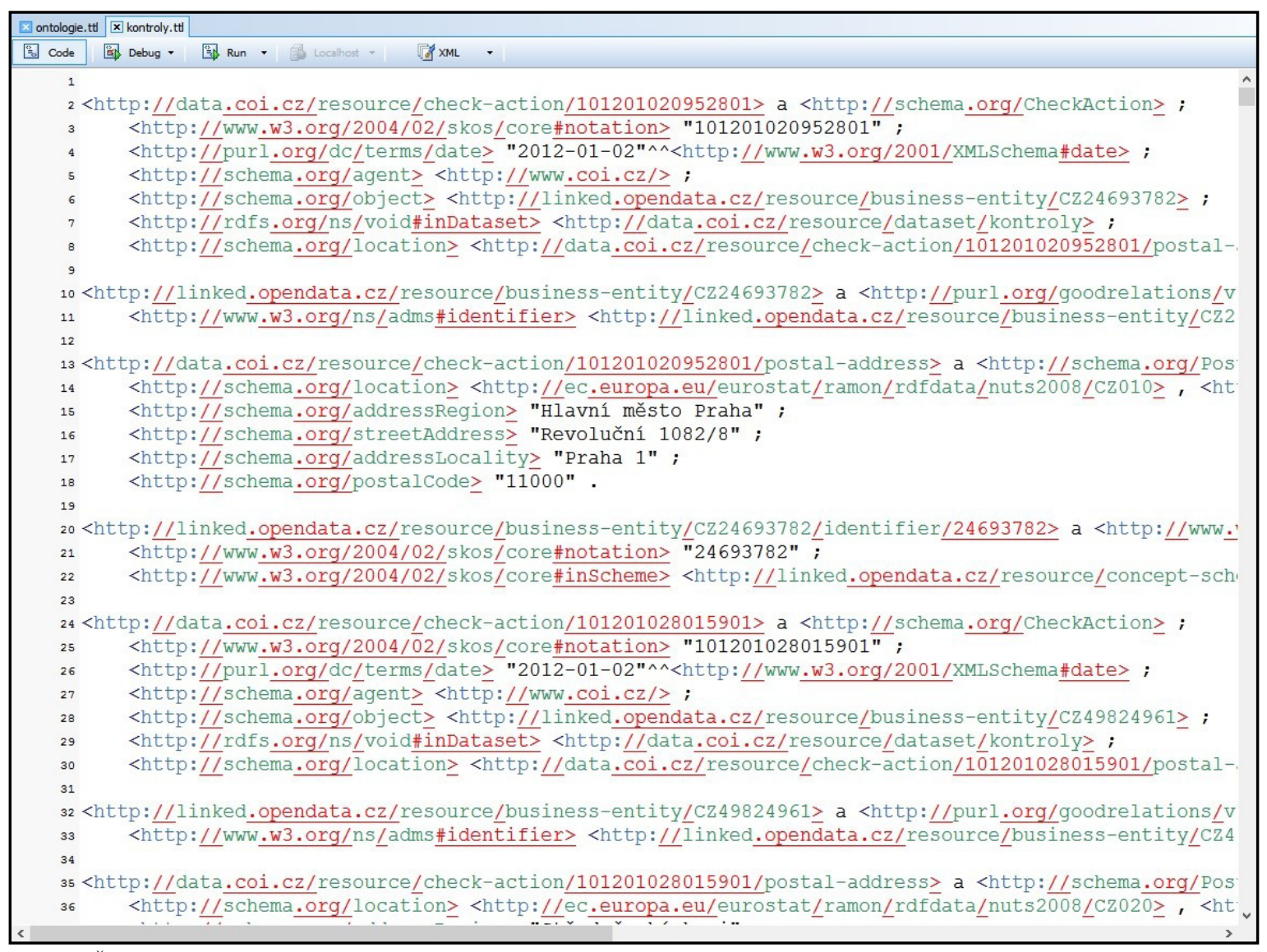

Source: (ČOI, 2013)

Figure 4: Example publishing open data in the format .rdf. 


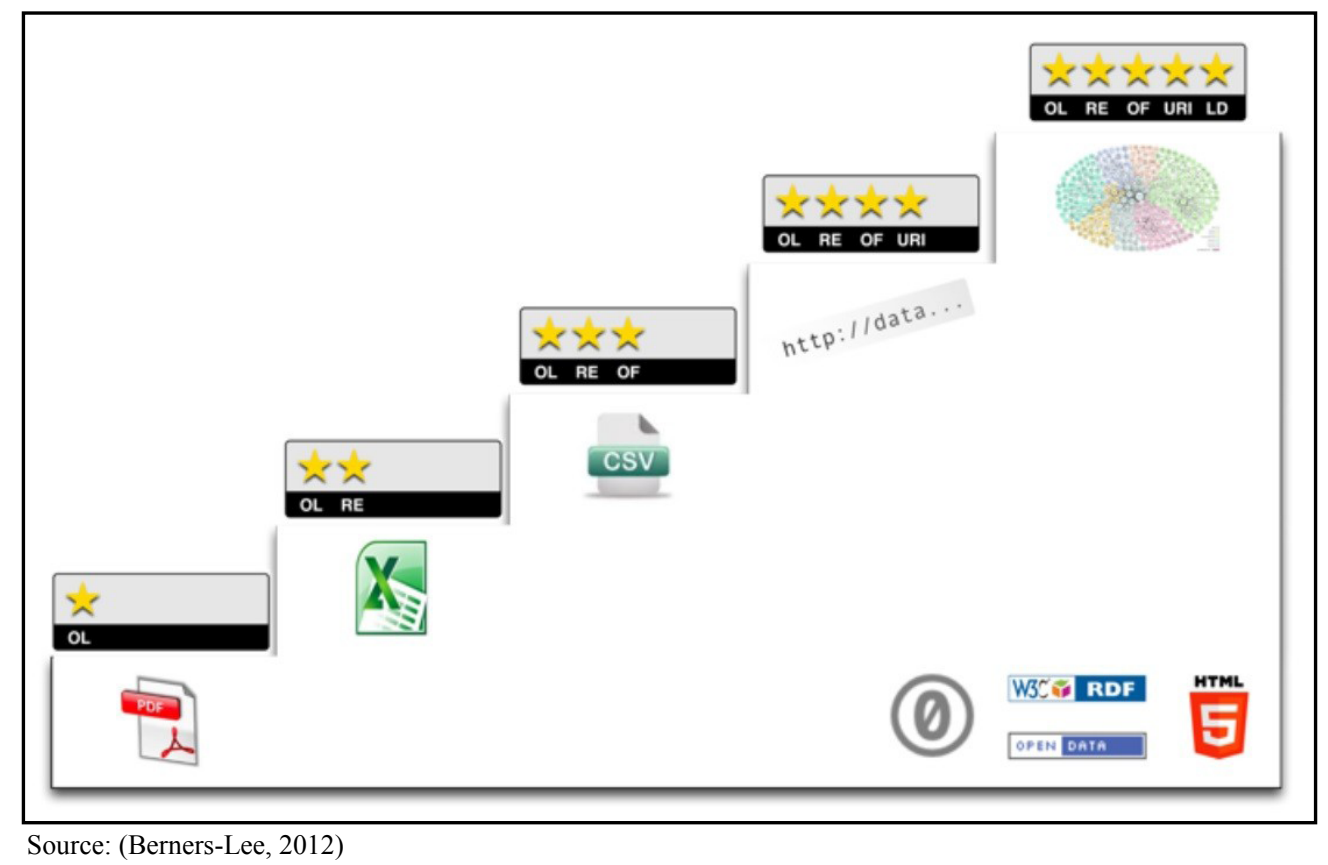

Figure 5: Degree of openness of the open data.

$H W$ is quality and level of hardware on part of the recipient.

Open data economy (economy based on open data) is often mentioned in conjunction with open data (Taggart, Peltola, 2010). There is no doubt that the agricultural sector must be a part of this economy. If agriculture should become a full-fledged part of this economy, it must accept open data. Current level of e-government in agriculture introduces a great opportunity to promote open data (Rysová et al., 2013).

\section{Agricultural e-government as an opportunity} to promote open data

In the Czech Republic, there is a good quality of e-government in the agriculture facilitated by the Czech Ministry of Agriculture (Rysová et al., 2013). Similarly to a classic e-government, this variant is being constantly developed in terms of its complexity and gradually aspires to the highest level, i.e. the level of a full-fledged e-government characterized by its relevant openness. The core component of the agricultural e-government in the Czech Republic is eAGRI portal maintained by the Ministry of Agriculture. In conjunction with the public sector, the need of so-called open e-government has been accented recently and the same variant should be considered in the case of an agricultural e-government, which means an open agricultural e-government. Its current level has all the capabilities to reach such quality (Figure 6).

An obvious need of value-added information dedicated to decision making in small and medium agricultural companies was identified during the previous research (Rysová et al., 2013). A lack of this information can be easily eliminated by open data through the open agricultural e-government. The gained information can then help the recipients (agricultural companies) to decide which suppliers to choose, how much to pay for their services or goods etc. This awareness then brings a greater strength in negotiations to the agricultural companies. It is worth to note that small and medium agricultural companies have gained focus of the European institutions not only from the viewpoint of subsidies but also the information support of their activities.

One of the objectives of agricultural e-government should be a relevant contribution to the satisfaction of the existing information needs. This means not only to gather the data from the agricultural companies, but also give the information back to these companies with some relevant added value. The added value may be the aggregation and analysis of the data. In this context, it can be concluded that the untapped potential of the current level of agricultural e-government can consist also in this function. 


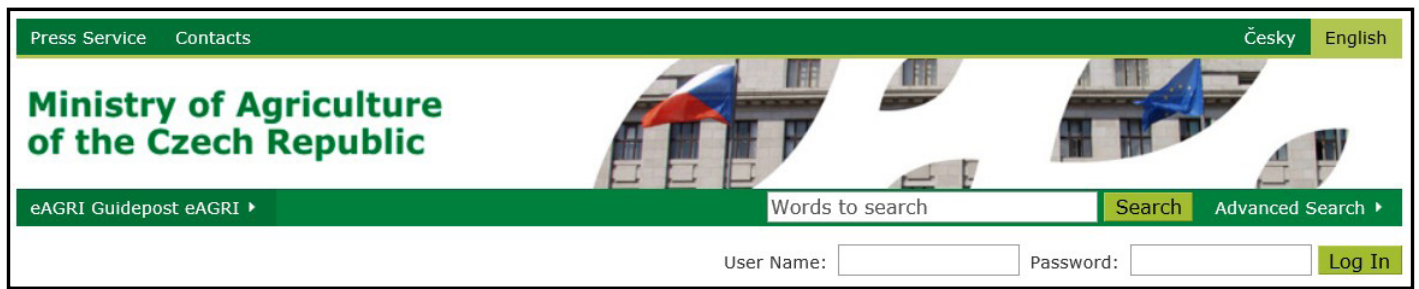

Source: (MZe, 2014)

Figure 6: Front page of the eAGRI Portal, the core component of agricultural e-government.

eAGRI Portal, as the core component of agricultural e-government, provides a wide range of opportunities for the proliferation of open data. One of these opportunities is the component "Evidence of the use of fertilizers and plant protection products". Within this application the users provide the Ministry of Agriculture with the data about these matters (Figure 7).

The data gathered by the application are then aggregated by the institution. It is possible to increase data value by analyses using a specialized software. After this evaluation the data can be returned to the source subjects who can use them to improve their decisions. The companies will learn which product is used regularly in their region or area, and thus is probably efficient. An information support like that can save a significant amount of money, because the cost of fertilizers and plant protection products is high and a wrong selection can result in a great loss. The eAGRI Portal offers a number of additional options of data evaluation and publishing that would be of great utility.

The disposition to use the eAGRI Portal in the way described above exists and is documented by the results of the above mentioned research project IGA nr. 20131038 at FEM CULS in Prague presented by the following Graph 3.

\section{The open data stimulus in the agricultural sector}

The supposed savings in the agricultural sector can represent only the first step of the economic benefit of open data. The prosperity of the economic subjects and the whole sector can be enhanced by activities that will bring new values (i.e. data with added value) that the agricultural companies will be willing to pay for. It is in the interest of the Ministry of Agriculture to make the data available to all parties with as low legal and licensing restrictions as possible and also in the highest possible technical quality. If the data are accessible in real time through a well-designed API, the number of interested subjects will be probably higher than in the case where the data are incomplete or only in basic Excel sheets.

The anticipated stimulus for the agricultural sector must be based on the elementary classification of subjects of the business model connected with open data and the roles of the subjects will be (Howard, 2013):

\section{- Suppliers}

Suppliers are the subjects who supply open data, although this activity is not necessarily their primary objective or the source of their profit. Publishing the data could be a part of their broader strategy to increase the trust of their customers and to strengthen their integrity. This business model includes primarily the companies who provide open data for better decisions of customers on the market. In the agricultural sector, this subject should be covered by the Ministry of Agriculture, and its primary objective should be the transparency of the whole sector.

\section{- Aggregators}

These institutions should collect and process the data. The core of their business will be in creating an added value by aggregating and processing the data and storing them in appropriate databases.

\section{- Developers}

These subjects should create mobile, web or information terminal (kiosk) applications and their target group will be end users. The applications can be offered free of charge or for a one-time payment for the download or use.

\section{- $\quad$ Enrichers}

These subjects should add some expert opinion to the data and this expertise should be offered as a service to the clients. Thus the original data will be enriched by some relevant added value that will be helpful to the customers.

\section{- Enablers}

This category brings the tools, methods 


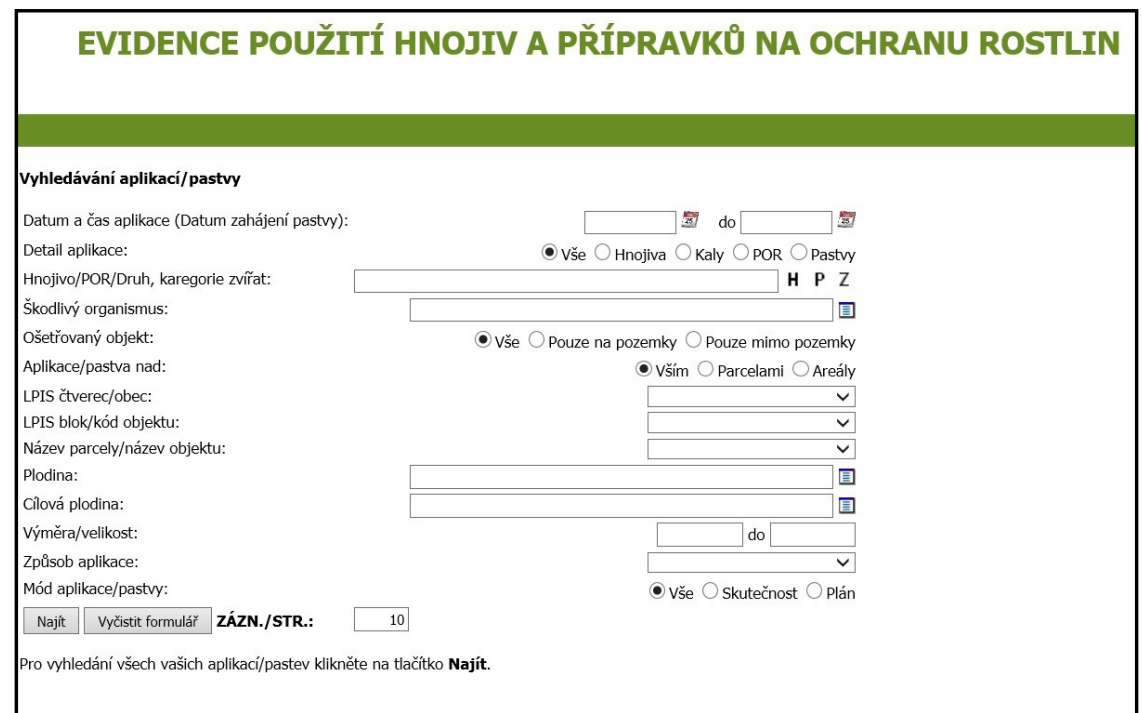

Source: (MZe, 2014)

Figure 8: The application Evidence of the use of fertilizers and plant protection products as a part of the eAGRI Portal.

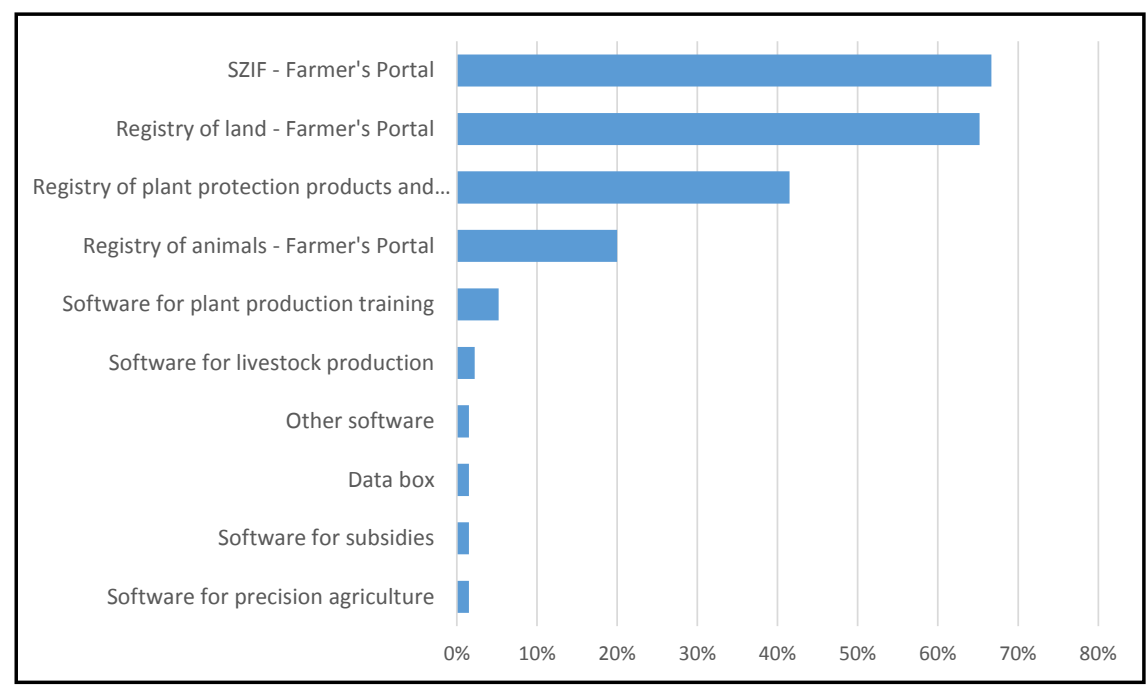

Source: own work

Graph 3: Training courses on the usage of the eAGRI Portal components.

and technologies that make the open data accessible for processing. Working with the data requires certain skill, whether on the side of the Ministry of Agriculture, which should publish the data, or the side of the parties who want to process them. It is important for potential users, if the data are available through a complex API (an intelligent interface) or as huge data files for download.

\section{Conclusion}

Gaining the full potential of open data in the agricultural sector assumes a good answer to the following questions:

- How can the transparency of open data help the agricultural companies in their business activities?

- Which data should be published?

- What quality must meet these data?

- How to efficiently make this data available in electronic form?

- Which facilities should be built for these purposes at the lower and middle management levels of the agricultural sector? 
- How to educate the officials at the Ministry of Agriculture and the middle managers of the agricultural companies to be attracted to open data?

- How to solve the dilemma between the publication of agricultural open data and the protection of strategic and personal data (Kučera, Chlapek, 2014)?

- Should the agricultural companies serve as and example and open their own data or should they support the existing activities on agricultural portals?

- How to support the companies to take part in open data?

If the above questions are successfully answered, the following benefits for the agricultural sector can be expected:

Corresponding author:

Doc. Ing. Václav Vostrovský, Ph.D.

Department of Information Engineering, Faculty of Economics and Management, Czech University of Life Sciences Prague, Kamýcká 129, 16521 Prague 6, Czech Republic

Phone: +420 22438 2039, E-mail: vostrovsky@pef.czu.cz

\section{References}

[1] Arzberger, P., Schroeder, P., Beaulieu, A., Bowker, G., Casey, K., Laaksonen, L., Moorman, D., Uhlir, P., Wouters, P. An International Framework to Promote Access to Data. Science. 2004, Vol. 303, No. 5665, p. 1777-1778. ISSN 00368075.

[2] Berners-Lee, Tim. 5 Star Open Data. 2012. [Online] Available: http://5stardata.info/ [Accessed: 25 Nov. 2012].

[3] Bertot, J. C., Choi, H. Big data and e-government: Issues, policies, and recommendations. ACM, 2013. p. 1-10. ISBN 978-145032057-3.

[4] Charvat, K., Esbri, M. A., Mayer, W., Campos, A., Palma, R., Krivanek, Z. FOODIE - Open data for agriculture. IEEE Computer Society, 2014. ISBN 978-190582444-1.

[5] Chui, M., Manyika, J., Van Kuiken, S. What Executives should Know about Open Data. McKinsey Quaterly. 2014, Iss. 1, p. 102-105. ISSN 0047-5394.

[6] ČOI. Open Data - Databáze Kontrol, Sankcí a Zákazů. Česká obchodní inspekce, 2013. [Online] Available: http://www.coi.cz/cz/spotrebitel/open-data-databaze-kontrol-sankci-a-zakazu [Accessed: 14 Dec. 2013].

[7] Cremin, J. D. Linking laboratory instruments for simulation: Comma separated variable files. ASEE, 2001. p. 6869-6875. ISBN 01901052.

[8] Dengel, A. The Role of Linked Data in Agriculture. Interview with Johannes Keizer, Information Systems Officer at the Food and Agriculture Organization of the United Nations. Organ des Fachbereichs „Künstliche Intelligenz“ der Gesellschaft für Informatik e.V. Springer-Verlag Berlin Heidelberg, 2013. November 2013, Vol. 27, No. 4, p. 363-364.

[9] Fu, Z., Sun, X., Zhou, L., Shu, J. New forensic methods for OOXML format documents. Springer Verlag, 2014. p. 503-513. ISBN 03029743.

[10] G-8. G-8 Open Data for Agriculture Conference Aims to Help Feed a Growing Population and Fulfill New Alliance for Food Security and Nutrition Commitment. Lanham, United States, Lanham: Federal Information \& News Dispatch, Inc., Apr. 29, 2013, 2013 ProQuest Central. 
[11] Howard, A. Governments Looking for Economic ROI must Focus on Open Data with Business Value. O‘Reilly Radar, February 25, 2013. [Online] Available: http://radar.oreilly.com/2013/02/roiopen-data-economy-value.html [Accessed: 16 Sept. 2014].

[12] Janssen, M., Charalabidis, Y., Zuiderwijk, A. Benefits, Adoption Barriers and Myths of Open Data and Open Government. Information Systems Management. 2012, Vol. 29, No. 4, p. 258-268. ISSN 1058-0530.

[13] Kjellberg, A., Werneman, A. Business Innovation - Innovative Teams, Competence Brokers and Beehive Structures - in a Sustainable Work Organisation. CIRP Annals - Manufacturing Technology. 2000, Vol. 49, No. 1, p. 355-358. ISSN 0007-8506.

[14] Klyne, G., Carroll, J. J. Resource Description Framework (RDF): Concepts and Abstract Syntax. 2006.

[15] Kučera, J., Chlapek, D. Benefits and Risks of Open Government Data. Journal of Systems Integration. 2014, Vol. 5, No. 1, p. 30-41. ISSN 1804-2724.

[16] Luna-Reyes, L. F., Bertot, J. C., Mellouli, S. Open Government, Open Data and Digital Government. Government Information Quarterly. 2014, Vol. 31, No. 1, p. 4-5. ISSN 0740-624X.

[17] MZe. Portál Farmáře (eAGRI). Ministry of Agriculture CR, 2014 [Online] Available: http://eagri.cz/ public/web/mze/farmar/ [Accessed: 17 Sept. 2014].

[18] Open Government Standards, 2012. [Online] Available: http://www.opengovstandards.org [Accessed: 20 Sept. 2012].

[19] Ř́hová, Z. Informační zabezpečení a organizační změny. University of Economics Prague, 1996. p. 99. ISBN 80-7079-535.

[20] Rysová, H., Kubata, K., Tyrychtr, J., Ulman, M., Šmejkalová, M., Vostrovský, V. Evaluation of Electronic Public Services in Agriculture in the Czech Republic. Acta Universitatis Agriculturae Et Silviculturae Mendelianae Brunensis. 2013, Vol. LXI, No. 2 , p. 473-479. ISSN 1211-8516.

[21] SVS. Mapové výstupy z kontrolní činnosti státní veterinární správy. State Veterinary Administration, 2014. [Online] Available: http://eagri.cz/public/app/svs_pub/mapy_vk/\#mapa=E07\&obdobi=R2014 [Accessed 16 Sept. 2014].

[22] Taggart, Ch., Peltola, V. OpenCorporates: Why we'Re Crying Out for this Database of Companies. The Guardian, 20 December 2010, 2010 [Online] Available: http:/www.theguardian.com/news/ datablog/2010/dec/20/open-corporates-chris-taggart [Accessed: 16 Sept. 2014].

[23] Tinholt, D. The Open Data Economy, Unlocking Economic Value by Opening Government and Public Data. Capgemini Consulting Analysis, 2013 [Online] Available: http://www.capgeminiconsulting.com/resource-file-access/resource/pdf/opendata_pov_6feb.pdf [Accessed: 16 Sept. 2014].

[24] Vostrovský, V., Tyrychtr, J., Ulman, M. The Potential of Agricultural eGovernment. MMK 2013 International Masaryk Conference for Ph.D. Students And Young Researchers. Ed. on-line: Magnanimitas, 2013. ISBN 978-80-87952-00-9.

[25] Weir, R. OpenDocument Format: The Standard for Office Documents. Internet Computing, IEEE. 2009, Vol. 13, No. 2, p. 83-87. ISSN 1089-7801.

[26] Zins, Ch. Conceptual Approaches for Defining Data, Information, and Knowledge. Journal of the American Society for Information Science and Technology. 2007, Vol. 58, No. 4, p. 479-493. [Online] Available: http://dx.doi.org/10.1002/asi.20508. [Accessed: 5 Jan. 2015]. ISSN 1532-2890.

[27] Zuiderwijk, A., et al. Socio-Technical Impediments of Open Data. Electronic Journal of E-Government. 2012, Vol. 10, No. 2, p 156-172. ISSN 1479-439X.

[28] Zuiderwijk, A., Janssen, M., Choenni, S., Meijer, R., Alibaks, R. S. Open Data Policies, their Implementation and Impact: A Framework for Comparison. Government Information Quarterly. 2014, Vol. 31, No. 1, p. 17-29. ISSN 0740-624X. 